\title{
Agricultural policy and nutrition outcomes - getting beyond the preoccupation with staple grains
}

\author{
Prabhu Pingali ${ }^{1}$
}

Received: 21 January 2015 / Accepted: 30 March 2015 / Published online: 14 May 2015

(C) The Author(s) 2015. This article is published with open access at Springerlink.com

\begin{abstract}
There is a growing disconnect between agricultural policy and contemporary nutritional challenges, the persistent problem of micronutrient malnutrition and child stunting, as well as the emerging challenges of overweight and obesity. Diversification of production systems and the market supply of enhanced diversity will only happen when the current distortions to farm and market level incentives are corrected. Data on the diet transition that is taking place across the developing world is presented and the growing divergence between staple crop demand and supply trends discussed. The reasons for the low producer response to rising demand for non-staple food, such as vegetables, are examined. Finally, the paper presents the main elements of a crop neutral agricultural policy, one that creates a level playing field which allows farmers to respond to market signals rather than a policy that is biased toward a particular set of crops.
\end{abstract}

Keywords Agriculture Policy · Nutrition - Diet diversity . Staple grain $\cdot$ Non-staple food $\cdot$ Policy bias

\section{Introduction}

The historic success of agricultural policy in ensuring adequate quantities of staple cereal grain and thereby beating

Special section series Strengthening the links between nutrition and health outcomes and agricultural research

Prabhu Pingali plp39@cornell.edu

1 Cornell University, Ithaca, NY, USA the problem of famine is well recognized. With that success the food security challenge itself has evolved in much of the developing world. It's no longer about enough calories, but rather about addressing malnutrition in its multiple dimensions. For the poor, it's about having access to adequate amounts of protein, micronutrients and vitamins. For the middle class it's about dealing with the emerging health concerns associated with overweight and obesity through better quality diets.

There is a growing disconnect between agricultural policy and contemporary nutritional challenges. It has been slow to respond to the persistent problem of micronutrient malnutrition and child stunting, as well as the emerging challenges of overweight and obesity. Agricultural policy is still heavily biased towards staple grain productivity improvement, especially for the big three cereal crops - rice, wheat and maizewhile the diet diversity needs of middle class as well as the poor are not adequately addressed. Policy actions taken after the 2008 food price crisis make it clear that most countries still interpret food security as staple grain self-sufficiency. Staple grain fundamentalism has constrained the ability of agricultural policies to achieve positive nutritional outcomes.

This paper proposes a crop neutral agricultural policy, one that creates a level playing field, which allows farmers to respond to market signals, rather than a policy that is biased toward a particular set of crops. Diversification of production systems and the market supply of enhanced diversity will only happen when the current distortions to farm and market level incentives are corrected. This paper presents data on the diet transition that is taking place across the developing world and the growing disconnect between staple crop demand and supply trends. The reasons for the low producer response to rising demand for non-staple food, such as vegetables, are examined. Finally, the paper presents the main elements of a crop neutral intensification strategy. 


\section{Diet transition - the declining share of staple cereals in developing country diets}

Income growth, urbanization, and global integration are all leading to dramatic changes in diets across the developing world. There is a palpable movement away from staple grains towards a diversified diet that includes higher shares of meat, dairy products, fats, sugar, fruit and vegetables (Pingali 2006; Popkin 2001). The pace of transition is faster in middle-income countries, countries such as China, Mexico, Thailand, and just starting in the rural areas of lower income countries, particularly those in sub-Saharan Africa. As a result of the diet transition one observes a decline in the per capita consumption of staple cereals and an associated increase in the number and quantity of non-staple cereal food groups that are consumed. This section provides data on the diet transition from FAO's Food Balance Sheets. While a FAO Food Balance Sheet does not provide data on actual food intake it is considered a good country level measure of aggregate average consumption. FAO Food Balance Sheets are commonly used for tracking aggregate trends in food consumption by agencies such as the FAO, World Bank, USDA and others. These data ought to be seen as a reflection of the average food basket for a particular country at a point in time.

FAO Food Balance Sheets indicate that the global average calorie consumption was around $2750 \mathrm{kcal} /$ capita/day for the period 2009-2011, having risen from $2350 \mathrm{kcal} / \mathrm{capita} /$ day in the 1969-1971 time period. Over the past four decades, average daily calorie consumption has risen by only 400 kilocalories, and indications are that the growth in total calories consumed, as a global average, has slowed down. There are, however, significant changes in the distribution of the calories by food groups, specifically the declining share of staples cereals in overall calories consumed (Fig. 1).

The overall share of staple cereal grains in the average global diet has fallen from $51 \%$ in 1970 to $46 \%$ in 2010. Most global forecasts agree that the share of staple cereals in total calories consumed will continue to decline into the foreseeable future (Rosegrant et al. 2001). In absolute terms, the global average per capita calorie consumption from staple cereals has leveled off at around $1300 \mathrm{kcal} / \mathrm{capita} /$ day and is expected to decline as we look towards 2030 and 2050 (FAO 2003). The decline in the share of staple cereal-based calories in total calories is much higher in the higher income countries relative to the lower income and middle income countries (Bruinsma 2003; Popkin 2001).

The stage of structural transformation that a country is in has a significant influence on its dietary diversity and the

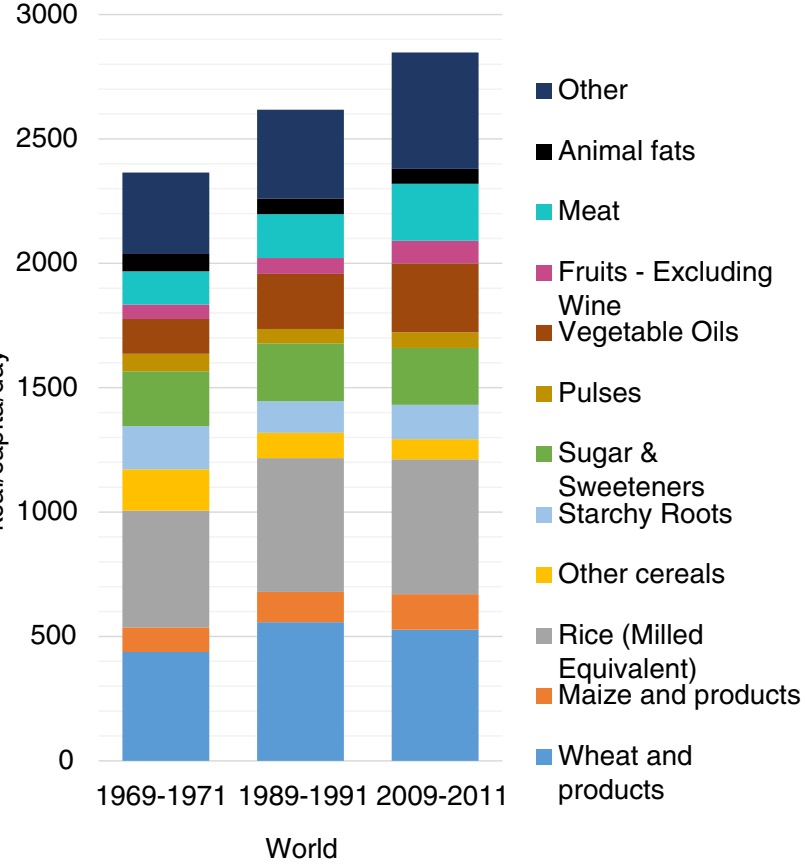

Fig. 1 Global average dietary composition by food group, 1969-2011 (FAO 2012)

importance of staple cereals in its diets. ${ }^{1}$ In Japan for instance, which is at the high end of the structural transformation process, the share of staple cereal-based calories in average daily calorie consumption declined from $48 \%$ in 1970 to $37 \%$ in 2010 (FAO Food Balance Sheets (FBS)). While Thailand, which is midway through the transformation process, has seen its share of calories from staple cereals drop from 72 to $46 \%$ during the same period. Kenya, which is at the lower end of the transformation process, continues to rely on staple cereals for providing more than half of its daily calorie needs.

So where are the additional calories coming from? Although varying by the stage of economic transformation, the major sources of calories that are substituting for cereals are, meat, dairy products, animal fats, vegetable oils, and sugars. Meat-based calories in average global diets have risen from $133 \mathrm{kcals} /$ day in 1970 to 230 in 2010 (FBS). Countries that are emerging into middle and higher income levels are seeing some of the fastest growth in meat consumption. China for instance, has seen per capita meat consumption rise from $78 \mathrm{kcals} /$ day in 1970 to $455 \mathrm{kcal} /$ day in 2010. Similar trends

\footnotetext{
${ }^{1}$ Structural transformation is the process by which societies are transformed from their rural origins towards increasing urbanization and employment outside the agricultural sector. Structural transformation is the defining characteristic of the development process; it is both the cause and the effect of economic growth. Four quite relentless and interrelated processes define the structural transformation process: (1) a declining share of agriculture in gross domestic product (GDP) and employment, (2) the rapid process of urbanization as people migrate from rural to urban areas, (3) the rise of a modern industrial and service economy, and (4) a demographic transition from high to low rates of births and deaths (Timmer 1998)
} 
are observed for other high value food groups. Vegetable fat consumption in India has risen from 101 to $210 \mathrm{kcal} / \mathrm{day}$. Sugar consumption in Thailand has risen from 84 to $384 \mathrm{kcal} /$ day. Diet transition is less obvious in Sub-Saharan Africa, but even there one observes similar trends in more rapidly growing countries such as Ghana (FAO 2014).

\section{Disconnect between staple cereal food demand and supply trends}

The bottom line from the discussion in the last section is that diet transition occurs as economies grow and, as individual income rises, there is a clear movement away from a dependence on staple cereal grains for providing a large share of the daily calorie requirements. Diets become increasingly diversified, both in terms of the number of food groups consumed as well as in terms of the quantity of diverse food that is consumed. Given the changing demand trends, one would anticipate food production to follow a similar pattern of diversification and that an eventual convergence of consumption and production trends would be observed. However, at the global and the national level, there is a significant disconnect between staple cereal food consumption and production trends.

Over the past four decades global aggregate cereal food consumption doubled in absolute terms, going from 500 million tons in 1970 to a billion tons in 2010. At the same time, global cereal crop production rose from 1.1 billion tons to 2.3 billion tons. The biggest production gains were made in rice, wheat and maize, the Green Revolution crops. Between 1970 and 2010, global wheat production doubled from around 322 million tons, maize production tripled from 282 million tons, and rice production went up by 2.3 times from 204 million tons. The above data and what follows come from FAOSTAT and FAO's Food Balance Sheets.

The gap between staple cereal crop production and the amount used for human food consumption has been widening steadily over the decades. In 1970, the surplus of grain production over food consumption was around 600 million tons; by 2010 it was close to 1.3 billion tons. Maize has the highest surplus of production over consumption, roughly 730 million tons in 2010, accounting for $57 \%$ of the total surplus. Rice accounts for only $8 \%$ of the surplus and wheat $18 \%$. So how is the surplus staple cereal grain production used? Approximately $60 \%$ of it goes towards animal feed, about a third goes towards industrial uses, such as biofuels and the rest goes to stocks (FAO 2014).

Maize accounts for the largest share of cereal grain used for feed, however significant quantities of wheat are also diverted to feed. FAO reports that in 2012/13 time period 801 million tons of cereal grain were used for animal feed, of this coarse grains (mainly maize) accounted for $82 \%$, and wheat accounted for $16 \%$ (FAO 2014). Biofuel, specifically ethanol production, is the other major source of diversion of staple food cereals, especially, maize. In the United States, roughly 120 million tons of maize was used for fuel ethanol production in 2012/13 and this is expected to climb to 130 million tons in 2014/15 (FAO 2014). Maize for ethanol production in the U.S has nearly doubled since 2007/08 when it was at 77 million tons. Policies that aim at providing cheap staple grain for the poor inadvertently help promote the inefficient use of the same grain for feed and fuel. A rise in relative price of staple cereals would trigger a search for more efficient livestock feed systems (see Mario and Thorton (2013)) and alternative feed stock for biofuel generation (Rendleman and Shapouri (2007).

There are of course regional differences in overall staple cereal production and utilization trends (as per data from FAOSTAT summarized below). South Asia, despite the concern of persistent and high levels of malnutrition, has seen a tripling of staple cereal production since 1970, due largely to the gains from the Green Revolution. South Asia enjoyed a surplus of production over food consumption of 60 million tons in 2010, up from around 10 million tons in 1970. Rice and wheat, the main food crops, account for $60 \%$ of the surplus (Fig. 2). Sub-Saharan Africa on the other hand, continues to experience a significant deficit in staple grains for food: roughly $35 \%$ of consumption is met through imports and aid. Wheat imports were at 13 million tons and rice at 5 million tons in 2010. Demand for rice and wheat has been growing rapidly in Sub-Saharan Africa, with limited potential for expanding domestic production, especially for wheat. Maize and other coarse cereal surpluses have risen to 32 million tons - almost twice that of 1990 — indicating a positive turnaround in productivity trends in Africa (Fig. 3).

Food stocks are an additional source of diversion of staple cereal production, and effectively managing these stocks is a major global and national food policy challenge. FAO's Food Outlook estimates that "World cereal stocks at the close of the

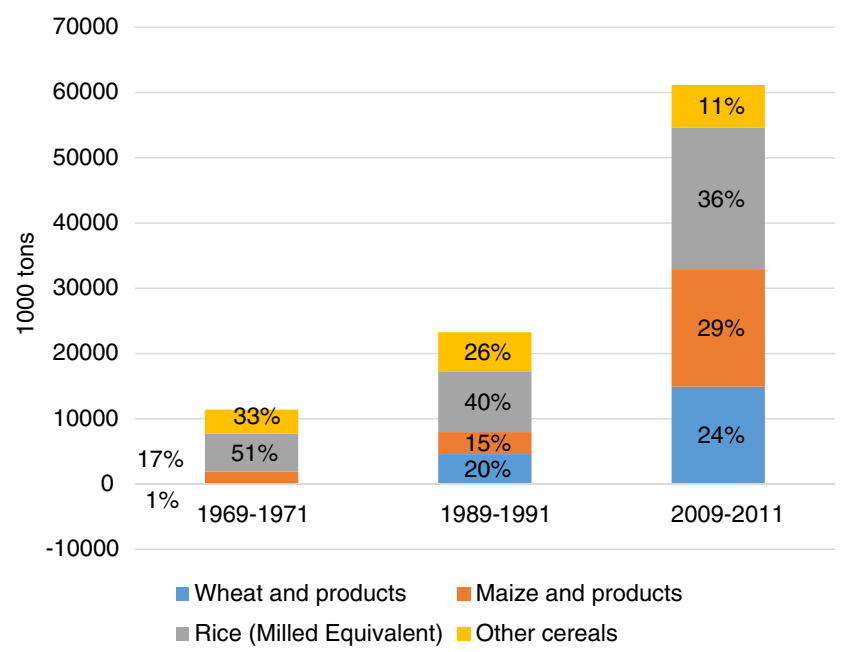

Fig. 2 Difference between total cereal production and total cereal consumption as food in Southern Asia, 1969-2011 (FAO 2012) 


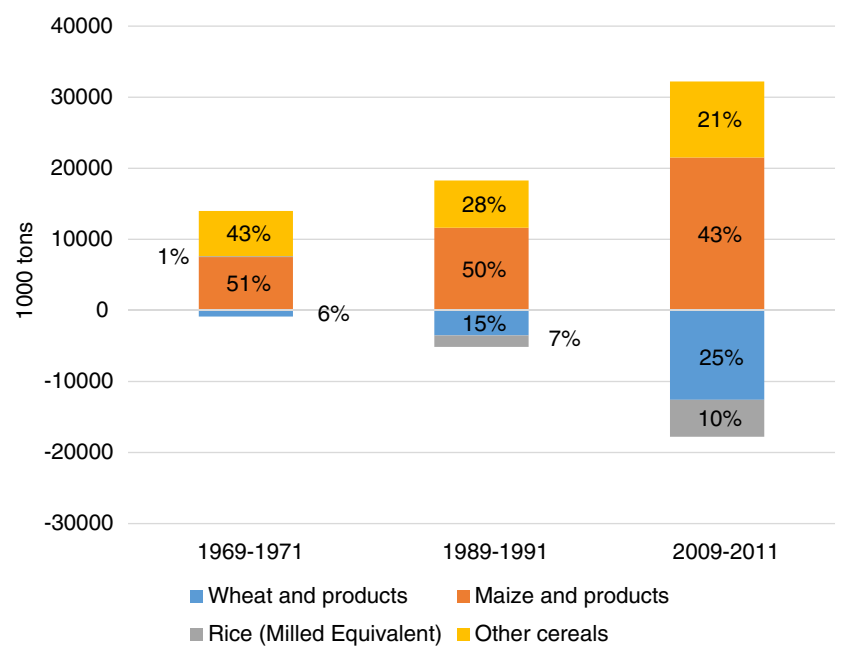

Fig. 3 Difference between total cereal production and total cereal consumption as food in Sub-Saharan Africa, 1969-2011 (FAO 2012)

crop seasons ending in 2015 would surge to 627.5 million tons, the highest level in 15 years" (FAO 2014). Global cereal stocks are currently at $57 \%$ of total food consumption requirement. Average annual cereal stocks have been around half a billion tons for the past decade (FAO 2014). Countries such as India have historically maintained high levels of food stocks and have increased them further after the 2008 food price crisis. Today, India holds 61 million tons of food stocks publically, amounting to $38 \%$ of annual food consumption requirements (Bhardwaj et al. 2014; FAO 2012). The costs of holding these stocks are enormous, and their disbursement has not been very effective, as has been documented by several observers (Cummings et al. 2006; McKee 2012). The huge reserves held by India are subject to significant losses, estimated to exceed $20 \%$ (McKee 2012). The 2012 Economic and Social Survey of Asia and the Pacific provides detailed information for Asian and Pacific countries on food stock management, as well as procurement prices and trade distortions in response to rising staple food prices (UNESCAP 2012, Table 3.6).

Pinstrup-Andersen (2015) provides empirical results from a multi-country study on the response to food price crises. He argues that the magnitude of food stocks is driven more by political economy factors associated with farm price policy rather than explicit policies towards managing a particular level of food stocks. In countries such as Zambia, Malawi and India, the rapid increase in food stocks was an (undesirable) outcome of price protection provided to farmers in response to the uncertainty created by global market instability. Pinstrup-Andersen found that in most cases, agricultural policy was driven by the desire to manage food prices at the farm and consumer level rather than a concern about not having enough food supplies. Responsibly releasing the high levels of stocks, without causing sharp price declines in the local or global markets, has been a major post-crisis challenge among the study countries. Countries tend to hold on to stocks despite the high cost of storage rather than release them in huge quantities in order to avoid distorting market prices.

To counter the above inefficiencies, IFPRI has proposed a model whereby individual countries maintain small physical food reserves for emergencies, and then cooperate in a larger, global food reserve. To prevent market price spikes resulting from speculation and hoarding, the plan would establish a virtual reserve that guarantees future prices through shortterm contracts. While this plan does not account for global emergencies caused by absolute worldwide food shortages, it does encourage individual countries to decrease their individual reserves and thus reduce international price volatility (Murphy 2009). Use of a regional reserve system has been shown to reduce costs by $41 \%$ (Koester 1986). Other solutions include shifting reserves to private institutions which tend to operate more efficiently, reducing the number of commodities held in reserve, and allowing wider margins between price floors and ceilings in order to decrease the number of times that the government must intervene to stabilize prices (Cummings et al. 2006). Gradually weaning farmers (and consumers) way from price subsidies for staple grains and enhancing the incentives for production system diversification into non-staple food crops and livestock products would also contribute to improved efficiencies in food stock management.

The bias towards promoting staple cereal grain production is clear when relative production trends are compared between staples and non-staples. Joshi et al. (2003) provide detailed data on the trends in staple and non-staple crop production in South Asia. They showed that despite strong diet diversification trends, supply has not kept up with demand. The paper estimates crop diversification indices that show the extent to which cropping systems are moving away from staple crop monoculture systems in South Asia. Joshi et al. argue that the movement towards high value fruit and vegetable production systems has been slow relative to the growth in demand. Lack of price incentives, infrastructure investments and high transactions costs associated with smallholder linkage to fruit and vegetable value chains are cited as the primary reasons for the slow supply response (See UNESCAP 2008 for related discussion for the Asia-Pacific Region). Further discussion on slow supply responsiveness is provided in the next section.

\section{Why is producer response for non-staple crop production so low?}

\section{Persistence of Green revolution era policy focus on staple grains}

At the start of the Green Revolution (GR), in the late 1960s and early 1970s, staple crop self-sufficiency was seen as 
fundamental to national food security (Pingali 2012). Agricultural R\&D and policies were predominantly focused on enhancing staple crop production, particularly in Asia. The rapid increase in agricultural output resulting from the GR came from an impressive increase in yields per hectare. Between 1960 and 2000, yields for all developing countries rose $208 \%$ for wheat, $109 \%$ for rice, and $157 \%$ for maize (FAO 2004). Developing countries in Southeast Asia and India were the first to show the impact of the GR varieties on rice yields, with China and other Asian regions experiencing stronger yield growth in the subsequent decades (Cassman and Pingali 1995). Similar yield trends were observed for wheat and maize in Asia. Analysis of agricultural Total Factor Productivity (TFP) ${ }^{2}$ finds similar trends to the partial productivity trends captured by yield per hectare (Fuglie 2010). For the period 1970-1989, change in global TFP for agriculture was $0.87 \%$, which nearly doubled to $1.56 \%$ from 1990 to 2006 (Fuglie 2010). Widespread adoption of GR technologies led to a significant increase in food supplies, contributing to a fall in real food prices.

Nutritional gains of the GR have been uneven; while overall calorie consumption increased, dietary diversity decreased for many poor people and micronutrient malnutrition persisted (Gómez et al. 2013). In some cases, traditional crops that were important sources of critical micronutrients (such as iron, vi$\operatorname{tamin} \mathrm{A}$, and zinc) were displaced in favor of the higher value staple crops (Webb and Eiselen 2009). For example, intensive rice monoculture systems led to the loss of wild leafy vegetables and fish that the poor had previously harvested from rice paddies in the Philippines (Pingali and Roger 1995). Price effects of such supply shifts further limited access to micronutrients as prices of micronutrient dense foods rose relative to staples in many places (Bouis 2000). In India, the increasing price of legumes has been associated with a consequent decline in pulse consumption across all income groups (Kataki 2002).

By the early 1990s there was a growing recognition that food security meant more than staple grain self-sufficiency need for a balanced diet that included protein, vitamins and other micronutrients, in addition to calories, was increasingly recognized (Herforth 2015). At the same time, rising incomes and urbanization were leading to a rise in demand for diet diversity as discussed above. Yet, the diversification of production systems away from staple cereals was slow, despite the rising relative prices of non-staples as discussed in the last section.

Policy and structural impediments, as well as a weak private sector, limited the supply responsiveness for vegetables

\footnotetext{
2 TFP measures the increase in total output that is not accounted for by the increase in total inputs. The difference could be due to technological innovation and/or overall efficiency improvements in the production process.
}

and other non-staples. Policies that promoted staple crop production, such as fertilizer and credit subsidies, price supports, and irrigation infrastructure (particularly for rice) tended to crowd out the production of traditional non-staple crops, such as pulses and legumes in India (Kataki 2002).

The persistence of staple grain fundamentalism in agricultural policy hampers farmer incentives for the diversification of their production systems. Policies that promoted staple crop productivity growth during the Green Revolution period are: output price support; crop specific input subsidies especially fertilizers; credit subsidies; grain procurement for food security stocks; and infrastructure investment that favors staple crop specialization, such as irrigation infrastructure. These policies have been hard to get rid of even after a country has achieved staple crop self-sufficiency and dietary diversification. Pingali (2012) provides a detailed review of Green Revolution policies and Bowman and Zilberman (2013) discuss how these policies hamper the movement towards a diversified cropping system.

\section{Poorly developed market infrastructure and high transactions costs of smallholder integration into the Fresh Fruit and Vegetable (FFV) and livestock value chain}

Markets for non-staples are extremely poorly developed in both traditional local markets as well as regional and national markets in much of the developing world. There is very little investment in transport systems, cold storage systems, and in information systems that allow for a better functioning of markets for perishable products such as fruits, vegetables, livestock products, etc. Public sector market development investments up until recently have been focused on the procurement of staple grains and the movement of staple grains from the farm into large storage systems and then through government distribution systems to urban consumers (McKee 2012). Private sector investment in market development has not been as widespread and that is an area where major investments need to be made, especially in building up value chains for perishable foods, fruits, vegetables, meat, milk, etc. In addition to the nutritional benefits of the enhanced supply of diverse food, significant poverty reduction benefits can also be observed where such investments promote smallholder integration into the value chain (Pingali et al. 2015). See McCullough et al. (2010) for an in-depth review of the prospects and constraints to smallholder participation in FFV value chains by the stage of economic development that a country is in.

The lack of supply responsiveness can also be explained by the need for new skills and new knowledge as farmers move from staple to non-staple grain production systems. Acquiring these new and specialized skills and knowledge, for production, processing, marketing of non-staples, is time intensive 
and costly (Reardon et al. 2012). If the incentive structure is not right, farmers will not make those investments in acquiring the new skills and new knowledge. Also, the transaction costs, associated with linking into new modern (fresh fruit and perishable product) value chains are very high, especially for smallholder farmers and in ensuring quality and safety. Smallholder farmers find these costs to be extremely daunting when thinking about making the transition from a focus on staple crops to moving to high value production systems (Pingali et al. 2005). Agriculture policies of Developing Countries need to be responsive to the changing demands placed on food systems and to actively support the process of diversification away from staple grains.

\section{Donor funding priorities are not consistent with the diet transformation $^{3}$}

Since the 1960s, donor assistance to agriculture and rural development has been a largely successful investment. Development assistance allocated to agricultural research, rural infrastructure, human capital development, and agricultural policy reforms has demonstrated the important contribution of agricultural development to poverty reduction and economic growth (Staatz and Eicher 1990; World Bank 2008). In general, the returns to agricultural development assistance have been positive, despite occasional failures resulting from poorly designed projects and policies. And within the broad category of agricultural development, agricultural research is often cited as the single, best investment in terms of increasing productivity and reducing poverty (Fan and Pardey 1997; Fan 2000; Fan et al. 2000).

Among many investments made in agricultural research during the past five decades, South Asia's Green Revolution — the doubling of yields and output of South Asia's major food staples between 1965 and 1985 - is one of the most often-cited examples of this high payoff (Hazell 2010; Pingali 2012). The public and private donors who financed many of these investments were considered visionaries of their time (Lele and Nabi 1991). The Ford Foundation and Rockefeller Foundation were the drivers behind the creation of an international agricultural research system focusing on major staple food crops (rice, wheat, and maize), while the World Bank and other members of the bilateral and multilateral donor community invested in the creation of a broader research network under the CGIAR umbrella.

Despite the success of the Green Revolution, or because of it, donor funding for agriculture research and productivity improvement infrastructure development declined sharply after the mid-1980s. The period between 1985 and 2005 are considered the "lost decades" for donor support of agricultural development (Pingali et al. 2014). This was a period of low

\footnotetext{
${ }^{3}$ This section draws from Pingali et al. 2014.
}

food prices and a general complacency about the need for further productivity improvement investments in agriculture (World Bank 2014). Unfortunately, this was also the period during which policy and investment support was badly needed for the diversification of agriculture away from its concentration on staple crops towards a broader set of crops, especially fruit, vegetables and legumes. The lost decades of donor support also resulted in a lost opportunity for promoting diversified post-Green Revolution farming systems.

Donor funding trends turned around by the middle of the first decade of the 2000s, after which significant new investment in agricultural development has been observed, both from traditional donors, as well as new bi-lateral donors, such as China, and philanthropies. Donor funding increased substantially after the 2008 food price crisis and the G8 Summit in L'Aquila in 2009. The latter set an agenda for responding to the crisis through investments in agricultural research and productivity improvements. For a detailed discussion of the current donor trends see Pingali et al. 2014. The L'Aquila Food Security Initiative (AFSI) resulted in pledges and a wider commitment to global food security from traditional bilateral donors, such as the European Union, United Kingdom and United States, as well as the traditional multilateral agencies, such as the World Bank. The European Union pledged US\$3.8 billion to agricultural development in response to AFSI in 2009. Similarly, the U.S. "Feed the Future" initiative committed US\$3.5 billion in 2010 over 3 years to results-driven programming in agricultural development and food security, targeting some of the world's poorest and most vulnerable countries and communities (Feed the Future 2011).

The World Bank reentered the field by expanding its investments in agricultural development lending and grants (World Bank 2014), while also assuming trusteeship of the Global Agriculture and Food Security Program (GAFSP). This initiative began in 2010 and made available an additional billion dollars to support strategic investments in national and regional agriculture and food security through both publicand private-sector financing (GAFSP 2011). Among the non-traditional donors, ${ }^{4}$ the Bill \& Melinda Gates Foundation accounted for $92 \%$ of the new investment in agricultural development. The renewed donor interest in agricultural development has also resulted in a significant boost in funding to the CGIAR, which now has an annual budget of a billion dollars from around 500 million in 2004 (Pingali et al. 2014).

Renewed donor interest has provided substantial new resources and has brought agriculture back on the agenda with a welcome focus on smallholder farmers. However, funding has

\footnotetext{
${ }^{4}$ The reference here is only to non-traditional donors and philanthropies that report their agricultural development assistance through the OECD's Creditor Reporting System (OECD-CRS).
} 
been disproportionately in favor of promoting growth of staple grain productivity. The vast majority of the grants made by GAFSP and USAID's "Feed the Future" initiative are targeted towards growth of staple grain productivity projects in the least developed countries (Feed the Future 2014). The 2014 Annual Report of Feed the Future (Table 1) indicates that improved varieties for staples, such as wheat, maize and rice were used on over 800 thousand hectares in the Feed the Future countries in 2013, while the comparable figure for horticulture crops was only around 29 thousand hectares. The substantial new funding from the Gates Foundation for agricultural development in sub-Saharan Africa and South Asia is explicitly focused on smallholder productivity growth and about half of the 2.5 billion dollars granted by the Foundation for Agricultural Development between 2006 and 2013 went towards staple crop R\&D. At least $30 \%$ of this was for productivity enhancing investments, such as improved access to seeds and inputs and investments in market infrastructure (Pingali et al. 2014). CGIAR's investment in the R\&D for the top three staple grains, rice, wheat and maize rose from approximately 100 million dollars in 2004 (CGIAR 2004) to 228 million dollars per year between 2012 and 2014 (CGIAR 2014). ${ }^{5}$ Given that the new funding resulted from the food price crisis of 2008 and concern about continued tightness of staple grain supplies, the focus on enhancing staple crop productivity is not surprising. However, it does tend to take attention away from the need to move towards a more diversified production system that is responsive to the changing food consumption patterns discussed in the first section of the paper.

\section{Towards crop-neutral agricultural policy}

A crop neutral agricultural policy is one that creates a level playing field, which allows farmers to respond to market signals rather than one that is biased towards a particular set of staple crops. In addition to correcting incentive bias, enhancing farmer ability to diversify production systems would also require high levels of public and private sector investment in transport, storage and market development. Investments are also required in reducing transactions costs for smallholder integration into markets for non-staple food.

Green Revolution era productivity-focused policies in addition to lowering food prices and expanding the available supply of staple cereal food, drove the process of structural transformation and stimulated growth in the non-agricultural

\footnotetext{
${ }^{5}$ The 2004 figure includes approximate expenditures of $\$ 5$ million for rice at CIAT, \$5 million for wheat at ICARDA and \$10 million for maize at IITA. The 2014 figures are annual averages over the 2012-2014 period and include an additional $\$ 10$ million for gene banks for the three crops and $\$ 10$ million for bio-fortification research specifically targeted towards the three crops by the CGIAR program "Harvest Plus".
}

sectors (Pingali 2010). Today, rising incomes and the prospect of declining per capita consumption of staple cereals in much of the developing world, with the exception of the least developed countries, implies that policy emphasis must shift from a focus on cereal intensification to one that encourages broader food supply diversification. Diversification of diets towards protein- and micronutrient-rich food provides new opportunities for agriculture-lead growth for smallholder farmers.

Given the connection between market linkages, economic growth, and dietary diversity, investments that can equip a diverse socioeconomic group of farmers (including smallholders) to participate are essential. Public policies aimed at creating an "enabling environment" and necessary institutions that encourage private sector investment lead to new market opportunities for farmers and thereby promote diversification. Market development investments include connective infrastructure (paved roads, telecommunication networks, networks for distribution), as well as mediating infrastructure (providing credit, credit rating agencies, property titles, and other legal and regulatory institutions that can depersonalize exchange transactions and make assets fungible) (De Soto 2000).

In particular, policies supporting household access to finance and land registration have been found to improve profitability (income), ensure greater on-farm productivity, and enable market access (Dercon 2002; Fafchamps 2009). Moreover, policies that succeed in creating an "enabling environment" for agriculture may improve equity by being inclusive of the rural poor who are less likely to have access to nonfarm employment, such as women farmers and the rural poor who are not literate or are recent immigrants (Barrett et al. 2001; Vanderpuye-Orgle and Barrett 2009). Finally, policy investments in market information technologies, product standardization, and food safety regulations can build consumer trust, identify new market demands, and provide meaningful opportunities for farmer response (Pingali et al. 2015).

\section{Conclusions}

Agricultural policy has played an important role in helping avert the specter of famine across the developing world by emphasizing staple crop productivity growth and enhancing staple food supplies. Nutritional gains of the Green Revolution have, however, been uneven: while overall calorie consumption increased, dietary diversity is likely to have decreased for many poor people and micronutrient malnutrition persisted. Policies that promoted staple crop production, such as fertilizer and credit subsidies, and price supports tended to crowd out the production of traditional non-staple crops that were important sources of critical micronutrients. Price effects of such supply shifts further limited access to micronutrients 
as prices of non-staple foods, such as fruit, vegetables and pulses rose relative to staples in many places.

Despite rising demand, the persistence of Green Revolution era policies and structural impediments, as well as a weak private sector, limited the supply responsiveness for vegetables and other non-staple food. Creating a "level policy playing field" that corrects the historical bias in favor of staple crops would help improve the incentives for diversification of production into non-staple foods. Agricultural policy of the past was focused on staple crop intensification. The need today, and into the future is a policy that is "cropneutral", removes distortions and allows farmers to respond to market signals in making crop production choices.

For many countries, food security still means adequate quantities of primary staple grains, such as rice or wheat. An holistic view of food security would require governments to ensure the availability of a wider basket of food, including food that is rich in micronutrients. Rationalizing food security policies, especially in terms of the balance in procurement and stocking of staple grains versus other nutritious food would be an important part of leveling the playing field for non-staples.

In addition to leveling the playing field, investments in road and transport infrastructure and cold storage systems are required for developing markets for perishable products. Also needed are investments for reducing the transaction costs associated with smallholders linking into the non-staple value chains. Investments in market information systems and farmer connectivity, especially through cell phones, could significantly cut transactions costs. Investments in general literacy as well as specialized training for farmers in meeting quality and safety standards for high value crops would help integrate smallholders into market value chains. Finally, institutional investments in establishing clear property rights to land and other assets, formalized contractual arrangements that depersonalize market transactions and access to finance (that is not tied to particular commodities) are essential for diversifying production systems.

Open Access This article is distributed under the terms of the Creative Commons Attribution 4.0 International License (http:// creativecommons.org/licenses/by/4.0/), which permits unrestricted use, distribution, and reproduction in any medium, provided you give appropriate credit to the original author(s) and the source, provide a link to the Creative Commons license, and indicate if changes were made.

\section{References}

Barrett, C. B., Reardon, T., \& Webb, P. (2001). Nonfarm Income diversification and household livelihood strategies in rural Africa: concepts, dynamics, and policy implications. Food Policy, 26(4), 315331.

Bhardwaj, M., Kumar, M., \& Das, K. N. (2014). Factbox - India's food stockpiling and WTO stand-off. Reuters. India. http://in.reuters. com/article/2014/07/29/uk-india-trade-stockpilesidINKBNOFY1AM20140729. Accessed 7 January 2015.

Bouis, H. (2000). Improving human nutrition through agriculture: the role of international agricultural research. Food and Nutrition Bulletin, $21,550-567$.

Bowman, M. S., \& Zilberman, D. (2013). Economic factors affecting diversified farming systems. Ecology and Society, 18(1), 33.

Bruinsma, J. (2003). World agriculture: towards 2015/2030. An FAO perspective. Rome: Food and Agriculture Organization of the United Nations/London, Earthscan.

Cassman, K. G., \& Pingali, P. L. (1995). Intensification of irrigated rice systems: learning from the past to meet future challenges. GeoJournal, 35, 299-305.

CGIAR. (2004). Financial report 2004, CGIAR. Washington: World Bank.

CGIAR. (2014). CGIAR Research Programs (CRP) financial report 2014. Washington: CGIAR Fund Office.

Cummings, R., Rashid, S., \& Gulati, A. (2006). Grain price stabilization experiences in Asia: what have we learned? Food Policy, 31(4), 302-312.

De Soto, H. (2000). The mystery of capital: Why capitalism succeeds in the west and fails everywhere else. New York: Basic Books.

Dercon, S. (2002). Income risk, coping strategies and safety nets. World Bank Research Observer, 17(2), 141-166.

Fafchamps, M. (2009). "Vulnerability, Risk Management, and Agricultural Development." Agriculture for development paper no. Afd-0904. Berkeley: Center of Evaluation for Global Action, University of California.

Fan, S. (2000). Research investment and the economic returns to chinese agricultural research. Journal of Productivity Analysis, 14(2), 163182.

Fan, S., \& Pardey, P. (1997). Research, productivity, and output growth in Chinese agriculture. Journal of Development Economics, 53, 115137.

Fan, S., Hazell, P., \& Thorat, S. (2000). Government spending, growth and poverty in rural India. American Journal of Agricultural Economics, 82(4), 1038-1051.

FAO. (2003). Agriculture towards the year 2015/30. Rome: Food and Agriculture Organization of the United Nations.

FAO. (2004). State of food and agriculture 2003/04. Rome: Food and Agriculture Organization of the United Nations.

FAO. (2012). FAOSTAT. Rome: Food and Agriculture Organization of the United Nations.

FAO. (2014). FAO food outlook 2014. Rome: Food and Agriculture Organization of the United Nations.

Feed the Future. 2011. Feed the Future. Accessed November 28, 2011. http://www.feedthefuture.gov/.

Feed the Future. (2014). Feed the future progress report 2014-accelerating progress to end global hunger. Washington: Feed the Future, USAID.

Fuglie, K. (2010). Total factor productivity in the global agricultural economy: Evidence from FAO data. In J. M. Alston, B. A. Babcock, \& P. G. Pardey (Eds.), The shifting patterns of agricultural production and productivity worldwide (pp. 63-98). Ames: Midwest Agribusiness Trade Research and Information Center, Iowa State University.

GAFSP (The Global Agriculture and Food Security Program). 2011. Accessed August 30, 2011. www.gafspfund.org/gafsp/content/ global-agriculture-and-food-security-program.

Gómez, M. I., Barrett, C. B., Raney, T., Pinstrup-Andersen, P., Meerman, J., Croppenstedt, A., et al. (2013). Post green revolution food systems and the triple burden of malnutrition. ESA working paper no 13-02. Rome: FAO.

Hazell, P. (2010). The Asian green revolution. In D. Spielman \& R. Pandya-Lorch (Eds.), Proven successes in agricultural development 
(pp. 67-97). Washington: International Food Policy Research Institute.

Herforth, A. (2015). Access to adequate nutritious food: new indicators to track progress and inform action. In D. Sahn (Ed.), The fight against hunger and malnutrition: The role of food, agriculture, and targeted policies. Oxford: Oxford University Press.

Joshi, P. K., Gulati, A., Birthal, P. S., \& Tewari, L. (2003). Agricultural diversification in South Asia: Patterns, determinants and policy implications. MSSD working paper 57. Washington: IFPRI.

Kataki, P. K. (2002). Shifts in cropping system and its effect on human nutrition: case study from India. Journal of Crop Production, 6, 119-144.

Koester, U. (1986). Regional cooperation to improve food security in southern and Eastern African countries, research report No. 53. Washington: IFPRI.

Lele, U., \& Nabi, I. (1991). Transitions in development: The role of aid and commercial flows. California: ICS.

Mario, H., \& Thorton, P. (2013). Livestock and global change: emerging issues for sustainable food systems. PNAS, 110(52), 20878-20881. doi:10.1073/pnas.1321844111.

McCullough, E., Stamoulis, K., \& Pingali, P. (Eds.). (2010). The tTrsformation of agri-food systems: Globalization, supply chains and smallholder farmers. London: Earthscan.

McKee, D. (2012). Strategic grain reserves. In B. Lilliston \& A. Ranallo (Eds.), Grain reserves and the food price crisis: Selected writings from 2008-2012 (pp. 33-35). Washington: Institute for Agriculture and Trade Policy.

Murphy, S. (2009). Strategic grain reserves in an era of volatility. Institute for Agriculture and Trade Policy, (October). Retrieved from http:// iatp.org/files/451_2_106857.pdf. Accessed 7 January 2015.

Pingali, P. L. (2006). Westernization of Asian diets and the transformation of food systems: implications for research and policy. Food Policy, $32,281-298$.

Pingali, P. L. (2010). Agriculture renaissance: Making 'agriculture for development' work in the 21st century. In P. Pingali \& R. Evenson (Eds.), Handbooks of agricultural economics (Vol. 4, pp. 3867 3894). Oxford: Elsevier B.V.

Pingali, P. L. (2012). Green revolution: impacts, limits and the path ahead. PNAS, 109(31), 12302-12308.

Pingali, P., \& Roger, P. (1995). Impact of pesticides on farmer health and the rice eco-system. Boston: Kluwer Academic Publishers.

Pingali, P., Khwaja, Y., \& Meijer, M. (2005). Commercializing small farms: Reducing transaction costs (No. 05-08). ESA working paper. Rome: FAO.

Pingali, P., Spielman, D., \& Zaidi, F. (2014). Changing donor trends in assistance to agricultural research and development in Africa South of the Sahara. In The Future of African Agricultural $R \& D$ (pp 6:1-6: 25). Washington, DC: IFPRI.

Pingali, P., Ricketts, K., \& Sahn, D. E. (2015). Agriculture for nutrition: Getting policies right. In D. Sahn (Ed.), The fight against hunger and malnutrition: the role of food, agriculture, and targeted policies. Oxford: Oxford University Press.

Pinstrup-Andersen, P. (Ed.). (2015). Food Price Policy in an Era of Market Instability - A Political Economy Analysis. London: Oxford University Press.

Popkin, B. M. (2001). The nutrition transition and obesity in the developing world. Journal of Nutrition, 131, 871S-873S.
Reardon, T., Timmer, C. P., \& Minten, B. (2012). Supermarket revolution in Asia and emerging development strategies to include small farmers. PNAS, 109(31), 12332-12337.

Rendleman, C. M., \& Shapouri, H. (2007). New technologies in ethanol production. Agricultural economic report number 842 . Washington: USDA.

Rosegrant, M., Paisner, M. S., Meijer, S., \& Witcover, J. (2001). 2020 global food outlook: Trends, alternatives and choics. Washington: International Food Policy Research Institute.

Staatz, J., \& Eicher, C. (1990). Agricultural development ideas in historical perspective. In C. Eicher \& J. Staatz (Eds.), Agricultural development in the third world. Baltimore: John Hopkins University Press.

Timmer, P. (1998). The agricultural transformation. In H. Chenery \& T. N. Srinivasan (Eds.), The handbook of development economics (Vol. 1). Amsterdam: North Holland Press.

UNESCAP. (2008). Economic and social survey of Asia and the pacific 2008. Bangkok: Economic and Social Commission for Asia and the Pacific.

UNESCAP. (2012). Economic and social survey of Asia and the pacific 2012. Bangkok: Economic and Social Commission for Asia and the Pacific.

Vanderpuye-Orgle, J., \& Barrett, C. B. (2009). Risk management and social visibility in Ghana. African Development Review, 21(1), 535.

Webb, P., \& Eiselen, H. (Eds.). (2009). Fiat Panis: For a world without hunger (pp. 410-434). Stuttgart: Hampp Media/Balance Publications.

World Bank. (2008). World development report. Washington: World Bank.

World Bank. (2014). Learning from World Bank history: Agriculture and food-based approaches for addressing malnutrition. Agriculture and environmental services discussion paper 10. Washington: World Bank.

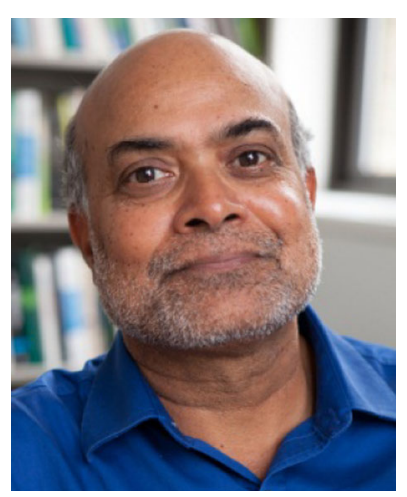

Prabhu Pingali Prabhu Pingali is a Professor in the Charles $\mathrm{H}$. Dyson School of Applied Economics and Management at Cornell University, with a joint appointment in the Division of Nutritional Sciences, and the Founding Director of the TataCornell Agriculture and Nutrition Initiative (TCi). Prior to joining Cornell, he was the Deputy Director, Agricultural Development Division of the Bill \& Melinda Gates Foundation, from 2008May 2013. Pingali has over three decades of experience working with some of the leading international agricultural development organizations as a research economist, development practitioner and senior manager. He has written 10 books and over 100 refereed journal articles and book chapters on food policy. 